Article

\title{
Variations of Groundwater Quality in the Multi-Layered Aquifer System near the Luanhe River, China
}

\author{
Qiaona Guo *, Zhifang Zhou, Guojiao Huang and Zhi Dou®
}

School of Earth Sciences and Engineering, Hohai University, Nanjing 210098, China; zhouzf@hhu.edu.cn (Z.Z.); jiaojiao.1986520@163.com (G.H.); douz@hhu.edu.cn (Z.D.)

* Correspondence: guoqiaona2010@hhu.edu.cn

Received: 24 December 2018; Accepted: 13 February 2019; Published: 15 February 2019

check for updates

\begin{abstract}
Nitrate pollution is an environmental problem in the North China Plain. This paper investigates the variation of groundwater levels and nitrate concentrations in an alluvial fan of the Luanhe river, northeast of the North China Plain. Three transects perpendicular to the riverbank were selected to investigate the exchange between river water and groundwater, and nitrate concentration with its isotopic composition $\left(\delta^{15} \mathrm{~N}-\mathrm{NO}_{3}\right.$ and $\left.\delta^{18} \mathrm{O}-\mathrm{NO}_{3}\right)$. The results showed that the groundwater level decreased slightly during the dry season, and increased regularly during the period of river stage rise. The groundwater is recharged by the river over 10 months each year. The nitrate concentration in the groundwater and river water varied with seasons. The nitrate concentration of groundwater in wells near the river is affected by the river water, which varied in basically the same way as the river. The nitrate concentrations in the zone of groundwater level depression cone were lower than those in the wells near the river, due to the long-term pumping of groundwater. However, the nitrate concentrations of river water have little influence on those of groundwater in wells far from the river. The values of $\delta^{15} \mathrm{~N}-\mathrm{NO}_{3}$ and the relationship between the two isotopes $\left(\delta^{15} \mathrm{~N}-\mathrm{NO}_{3}\right.$ and $\left.\delta^{18} \mathrm{O}-\mathrm{NO}_{3}\right)$ suggested that $\mathrm{NO}_{3}-\mathrm{N}$ was mainly attributable to sewage, livestock manure and natural soil organic matter. Due to the existence of a groundwater depression cone near the river, nitrate contamination can be transported into the aquifer with the flow. The average time lag of nitrate migration from the river to the zone of groundwater level depression cone is different in different sections, which shows an increasing trend from the upstream to downstream along the river, with an average of two to six months. It is mainly related to the stratigraphic structure, the migration distance, the hydraulic conductivities of the aquifer and the riverbed sediment. Compared with the case of considering the silt layer, the time lag of nitrate migration is greater than that of the case of ignoring the silt layer. The results will provide useful information for detecting nitrate concentrations in the alluvial fan area of the Luanhe river, northeast of the NCP (North China Plain).
\end{abstract}

Keywords: groundwater level; nitrate contamination; isotopes; luanhe river

\section{Introduction}

Riparian zones are defined as a transition area between the terrestrial and aquatic ecosystems $[1,2]$. They play a crucial role in ecological systems and biodiversity because of the interaction of groundwater from inland and the river water from stream. Therefore, it is essential to understand the dynamics of exchange between surface water and groundwater. Aquifer-stream interaction occurs continuously and can transit between gaining and losing depending on many natural factors, including stream water level, stream bank slope, hydraulic properties of stream bed, groundwater table depth, and aquifer's hydraulic properties [3-6]. In addition, human activities also impact stream-aquifer interaction, such as 
groundwater pumping near a stream, which has resulted in a decrease of groundwater table, causing aquifer depletion and water quality degradation. Therefore, understanding the hydraulic connectivity between streams and alluvial aquifers is a requirement for sustainable utilization of water resources, both for groundwater and surface water management.

The nitrate contamination in groundwater has become an environmental problem worldwide, especially in countries where groundwater is the main source of potable water. The research shows that nitrate is the most frequent pollutant in groundwaters [7-9]. Since the end of the twentieth century, many countries and regions in Europe and America have carried out research on the influencing factors and control counter measures of nitrate pollution in groundwater [10-12]. In many parts of China, groundwater is also polluted by nitrate to varying degrees [13]. The northeast of the North China Plain (NCP) is known as a hotspot of severe groundwater depletion caused by irrigation, and the intensive use of nitrogen fertilizers has led to increasing groundwater nitrate pollution which, in places, exceeds the national maximum concentration for drinking water of $45 \mathrm{mg} / \mathrm{L}$ [14]. Nitrate pollution is a serious problem affecting drinking water for a vast population. Nitrate leaching to groundwater has been found to be related to Nitrogen surpluses, hydrological conditions, land use and soil type [15]. In response to this concern, there is a need for field observations and examination of the dispersal of nitrate pollutants in groundwater systems. Recently, an increasing number of studies on this specific topic and in this area have been carried out, including the field observations, data analysis and numerical modelling [13,14,16-18]. However, the data are still scarce with respect to the nitrate concentration affected by the overexploitation and fertilizers.

Understanding the nitrate sources and transformation processes is critical to detecting nitrate pollution $[19,20]$. In contaminated zones, nitrate isotopes $\left(\delta^{15} \mathrm{~N}_{-N_{3}}, \delta^{18} \mathrm{O}^{-\mathrm{NO}_{3}}\right)$ can be used to identify the source of nitrogen as mineral or organic fertilizer, sewage, or atmospheric deposition [21-23]. The isotope mass-balance mixing models based on the $\delta^{15} \mathrm{~N}-\mathrm{NO}_{3}$ and $\delta^{18} \mathrm{O}-\mathrm{NO}_{3}$ approach have been used to quantify nitrate sources $[21,24,25]$. The method of combining isotopes and multivariate statistical analysis was also used to analyze the nitrate source in groundwater in multiple land-use areas [26]. The $\delta^{15} \mathrm{~N}-\mathrm{NO}_{3}$ composition of most nitrate sources falls between $-10 \%$ and $+25 \%$ [27]. The $\delta^{18} \mathrm{O}-\mathrm{NO}_{3}$ of atmospheric nitrate shows a wide range between $+25 \%$ and $+70 \%$, and that of organic fertilizer has a value ranging from +17 to $+25 \%$ o $[20,28,29]$.

In the vicinity of rivers, nitrate may be retained, transformed, or degraded by microbial communities [30]. Here, the interaction between surface water and groundwater has an obvious influence on the migration process of nitrate of groundwater. Time series of contamination concentrations have been used to determine the travel time of river water into aquifers induced by pumping [31-33]. However, there is a time lag for the nitrate movement from the surface water into the groundwater which depends on the aquifer properties [34]. Therefore, determining the duration of time lag is of critical importance for mastering the mechanism of nitrate transport.

In the alluvial fan area of the Luanhe river, northeast of the NCP, groundwater is an important resource to be used for domestic, agricultural and industrial purposes, due to the lack of quantity of surface water resources. The previous research focused on the environmental geologic problem in the alluvial fan of the piedmont plain zone, such as the decrease of groundwater table and land subsidence [35]. Huang et al. [36] analyzed the characteristics of the shallow groundwater quality in the alluvial fan area of the Luanhe river, North China. However, there is no report on nitrate pollution in this area, including nitrate distribution in groundwater, identification of pollution sources, and influencing factors. In this paper, we present field measurements of water table and nitrate concentration in the wells of the alluvial fan area of Luanhe river, North China. The environmental isotopic tracers $\delta^{15} \mathrm{~N}-\mathrm{NO}_{3}$ and $\delta^{18} \mathrm{O}-\mathrm{NO}_{3}$ were used to determine the nitrate sources. The propagation time of nitrate into the aquifers following the river rise was estimated. The primary objectives of the study are to (1) quantify the nitrate concentration of groundwater and its isotopic composition, (2) identify the sources of nitrate pollution, and (3) estimate the time lag of nitrate in the Luanhe River 
transporting from the river to adjacent alluvial aquifer. The results will provide useful information for detecting nitrate concentrations in the alluvial fan area of the Luanhe river, northeast of the NCP.

\section{Study Site Description}

\subsection{Study Area}

Our study area is located in the northeast of Luan county, Hebei Province, China. It is situated in the west of Luanhe River, the south of Yanshan Mountains, with a latitude $39^{\circ} 42^{\prime} 51^{\prime \prime}$ to $39^{\circ} 45^{\prime} 03^{\prime \prime}$ and a longitude $118^{\circ} 44^{\prime} 56^{\prime \prime}$ to $118^{\circ} 45^{\prime} 54^{\prime \prime}$ (Figure 1). Luanhe alluvial plain is a compound alluvial fan located at the front of the Yanshan Mountains, covering the northeastern part of the North China Plain. The study region is located in the front edge of the alluvial plain formed by Luanhe River. The elevation of the relief topography is between $20 \mathrm{~m}$ and $30 \mathrm{~m}$. About $20 \%$ of the study area has been covered by forest, and $80 \%$ of it is covered by crops (wheat and corn). The area has a continental, semi-humid climate with an average annual temperature of $10.5^{\circ} \mathrm{C}$. Annual rainfall in this area is around $636.7 \mathrm{~mm}$, and $86 \%$ of precipitation occurs from July to September. The mean annual pan evaporation is $1030.9 \mathrm{~mm}$. The major surface water resource in the area is the Luanhe River. In Luan county, the river has a length of $41 \mathrm{~km}$ from North to South, a drainage area of $91 \mathrm{~km}^{2}$, and a streambed width of $700 \mathrm{~m}$ to $1100 \mathrm{~m}$.

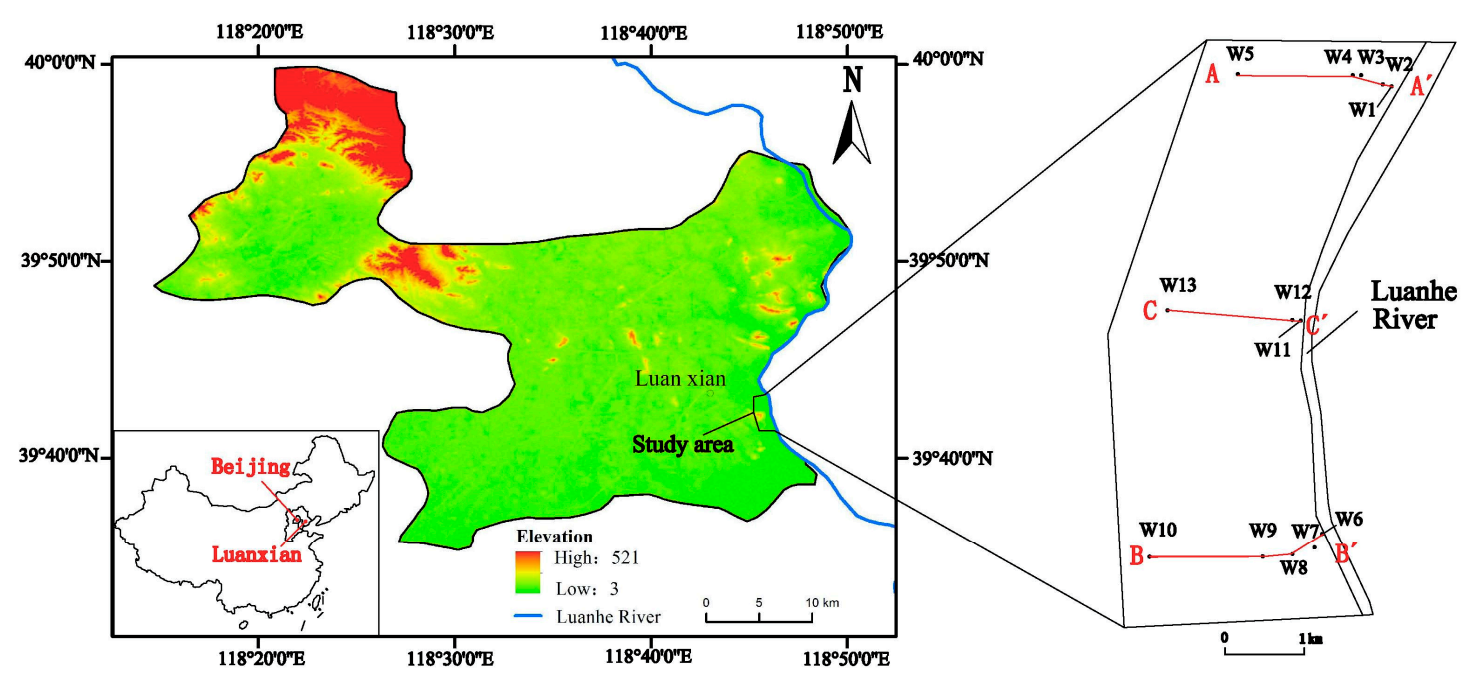

Figure 1. Location of the observation wells and cross-sections in the study area.

\subsection{Field Site}

The field survey showed that groundwater in the alluvial aquifer was contaminated on both sides of the river. Therefore, three hydrogeological cross sections were selected from north to south of the study area along Luan River, as shown in Figure 1. The monitored transects were arranged in the right bank side of the river, taking into account the symmetry. The distance between the upstream cross section $A-A^{\prime}$ and downstream cross section $B-B^{\prime}$ is about $5.5 \mathrm{~km}$. There are five monitoring wells ('W') placed on the cross sections A-A' and B-B', respectively. W1 from the A-A' and W6 from the B-B' sections are situated in the river flood plain, and the distance of both W1 and W6 from the Luanhe river is $10 \mathrm{~m}$. The middle cross section C-C' consisted of three wells W11-W13, which are $20 \mathrm{~m}, 50 \mathrm{~m}$ and $800 \mathrm{~m}$ away from the river bank, respectively. Therefore, there are a total of thirteen monitoring wells in the study area, as shown in Figure 1, which are suitable for local study. More details about the field arrangement can be found in Huang et al. [36]. Some parameters related to the wells are listed in Table 1. 
Table 1. Wells parameters.

\begin{tabular}{cccccc}
\hline Well No. & Longitude & Latitude & Well Depth (m) & Borehole Elevation (m) & $\begin{array}{c}\text { Length of Well } \\
\text { Filter (m) }\end{array}$ \\
\hline W1 & $118^{\circ} 45^{\prime} 53^{\prime \prime}$ & $39^{\circ} 44^{\prime} 57^{\prime \prime}$ & 6.5 & 23.39 & 3 \\
W2 & $118^{\circ} 45^{\prime} 49^{\prime \prime}$ & $39^{\circ} 44^{\prime} 58^{\prime \prime}$ & 7 & 27.54 & 3 \\
W3 & $118^{\circ} 45^{\prime} 47^{\prime \prime}$ & $39^{\circ} 45^{\prime} 01^{\prime \prime}$ & 23.5 & 28.05 & 8 \\
W4 & $118^{\circ} 45^{\prime} 45^{\prime \prime}$ & $39^{\circ} 45^{\prime} 01^{\prime \prime}$ & 19 & 27.27 & 8 \\
W5 & $118^{\circ} 45^{\prime} 25^{\prime \prime}$ & $39^{\circ} 45^{\prime} 03^{\prime \prime}$ & 28 & 33.06 & 6 \\
W6 & $118^{\circ} 45^{\prime} 35^{\prime \prime}$ & $39^{\circ} 42^{\prime} 59^{\prime \prime}$ & 6.5 & 22.51 & 3 \\
W7 & $118^{\circ} 45^{\prime} 28^{\prime \prime}$ & $39^{\circ} 42^{\prime} 55^{\prime \prime}$ & 7.0 & 22.62 & 3 \\
W6 & $118^{\circ} 45^{\prime} 28^{\prime \prime}$ & $39^{\circ} 42^{\prime} 52^{\prime \prime}$ & 10 & 24.4 & 7 \\
W9 & $118^{\circ} 45^{\prime} 20^{\prime \prime}$ & $39^{\circ} 42^{\prime} 51^{\prime \prime}$ & 19 & 24.22 & 7 \\
W10 & $118^{\circ} 45^{\prime} 09^{\prime \prime}$ & $39^{\circ} 42^{\prime} 52^{\prime \prime}$ & 19 & 24.32 & 5 \\
W11 & $118^{\circ} 45^{\prime} 27^{\prime \prime}$ & $39^{\circ} 43^{\prime} 44^{\prime \prime}$ & 14 & 27.18 & 5 \\
W12 & $118^{\circ} 45^{\prime} 23^{\prime \prime}$ & $39^{\circ} 43^{\prime} 47^{\prime \prime}$ & 13 & 25.34 & 4 \\
W13 & $118^{\circ} 44^{\prime} 56^{\prime \prime}$ & $39^{\circ} 43^{\prime} 53^{\prime \prime}$ & 10 & 27.74 & \\
\hline
\end{tabular}

\subsection{Geology and Hydrogeology}

Based on the boring logs and high-density resistivity method, the stratigraphic structure at different cross section was identified. Sediments types include silty sand, clay, and gravel from the top to bottom (Figure 2). The sand layer and gravel layer are distributed continuously; however, the intermediate clay layer is discontinuous. The thicknesses of the silty sand, clay and gravel are about $1-7 \mathrm{~m}, 0-15 \mathrm{~m}$ and $8-23 \mathrm{~m}$, respectively. In the vertical profile from the top to bottom, the particle size of various components is from fine to coarse, with a typical dual structure. The bottom of the sediments is bedrock, which is about $30 \mathrm{~m}$ below the surface based on the high-density resistivity method. The hydraulic conductivities of the layers are estimated based on the pumping test and slug test data. The permeability of the upper sand layer and lower gravel layer is high, and the hydraulic conductivities of these two layers are 1-6 and 100-350 m/day, respectively. The permeability of middle clay layer is relatively low, and the hydraulic conductivity of which is $0.01-0.1 \mathrm{~m} /$ day. The well W5 is located in a second-grade terrace, while the other wells are distributed in a first-grade terrace. The permeability of the layers increases with depth gradually. In the direction perpendicular to the river, the thickness of the silty sand and gravel become thin gradually, and that of clay increases. Therefore, the permeability of the aquifer near the river bank is greater, whereas it decreases far away from the river bank. Along the river longitudinally, from the upstream section $\mathrm{A}-\mathrm{A}^{\prime}$ to downstream section $\mathrm{B}-\mathrm{B}^{\prime}$, the thickness of sand and gravel becomes thin gradually, and the thickness of clay increases. Thus, the permeability of the layers has a decreasing trend from the upstream to downstream of the river.

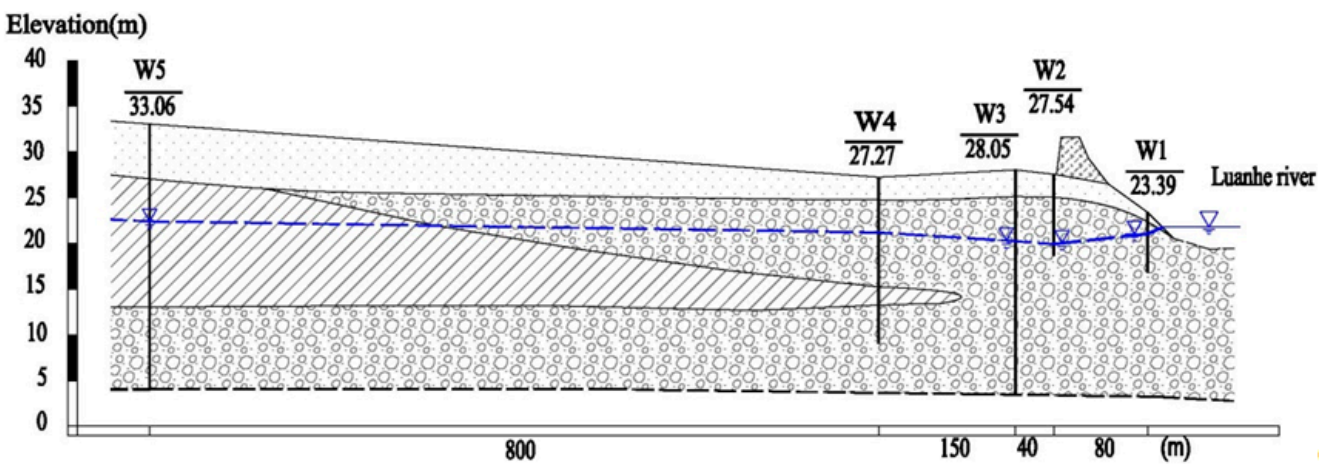

(a)

Figure 2. Cont. 


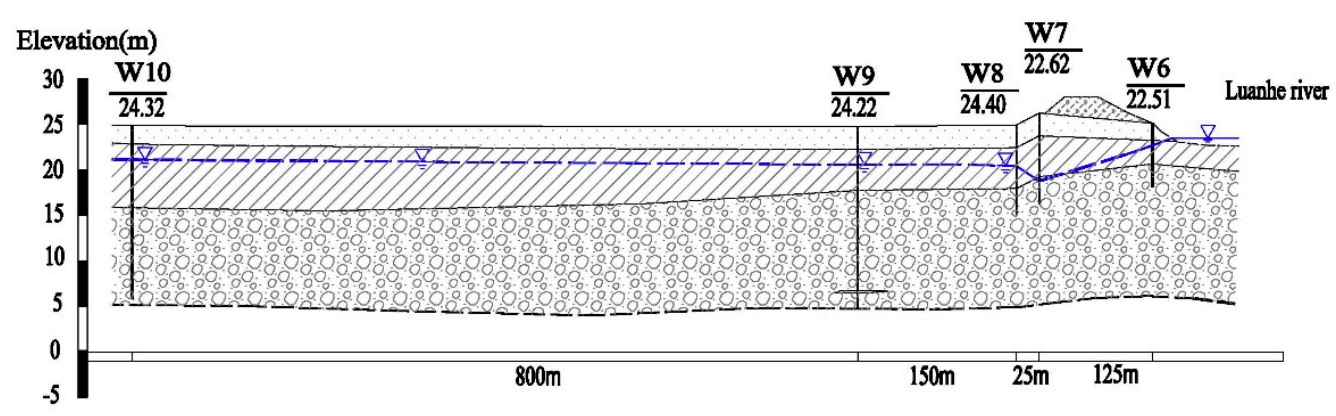

(b)

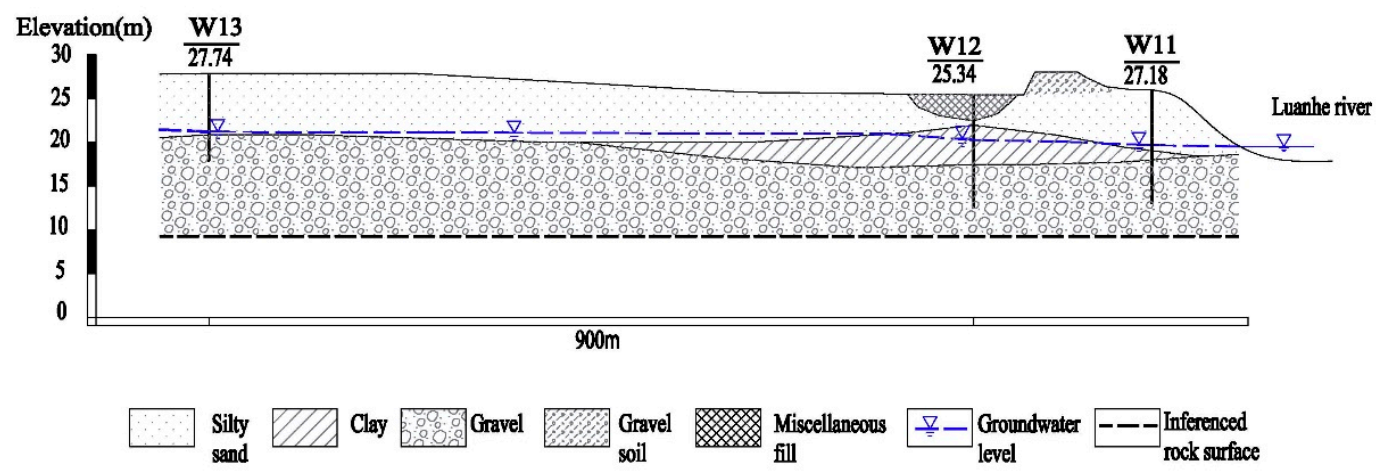

(c)

Figure 2. Schematic hydrogeological cross section of the Luanhe alluvial fan and groundwater level change along (a) transect $A-A^{\prime},(\mathbf{b})$ transect $B-B^{\prime}$ and (c) transect $C-C^{\prime}$.

\section{Materials and Methods}

\subsection{Groundwater Level and Quality}

Measurements of groundwater level and the river stage were conducted manually at time interval of five days from 11 November 2010 to 11 September 2011. Groundwater and river water samples were collected at time interval of two months from November 2010 to September 2011, and then they were transported to the laboratory for chemical analysis of major ions and nitrate concentration. In order to avoid the air entering groundwater during the sample, the observed wells were sampled for water quality at a depth $1 \mathrm{~m}$ below the groundwater level. Samples were collected using $1 \mathrm{~L}$ bottles and labeled. In brief, all wells were pumped for about $10 \mathrm{~min}$ before sampling using a 3-inch water pump. There were only twelve samples from wells at each time, because well W4 was destroyed.

In the current study, the focus was on nitrate in the wells sampled once every two months from November 2010 to September 2011. Huang et al. [36] provided the details of the sampling and analysis procedures for the major ion concentrations. The dissolved nitrate was analyzed spectrophotometrically on an automated ion flow injection analyzer (QuickChem Methods 10-107-04-1-C). The other physical parameters such as electrical conductivity (EC), total dissolved solids (TDS), and temperature and $\mathrm{pH}$ of the samples were measured in the field using portable EC and $\mathrm{pH}$ meters.

Isotopic compositions of ${ }^{18} \mathrm{O}$ and ${ }^{15} \mathrm{~N}$ are reported using the standard per mil ( $\delta$ ) notation, which are calculated in terms of the $\%$ deviation of the isotope ratio of the sample relative to the ratio in the V-SMOW(Vienna Standard Mean Ocean Water) standard. $\delta^{18} \mathrm{O}$ was prepared using the $\mathrm{CO}_{2}$ equilibration method [37]. Reproducibility of the samples calculated from standards systematically interspersed in the analytical batches was $\pm 0.20 \%$ for $\delta^{18} \mathrm{O}$. The dissolved $\mathrm{NO}_{3}{ }^{-}$ is first transformed to $\mathrm{AgNO}_{3}$ and then combusted to $\mathrm{N}_{2}$ in sealed quartz tubes for $\delta^{15} \mathrm{~N}$ analysis through a gas chromatograph into a Thermo-Finnigan Delta Plus isotope-ratio mass spectrometer. 


\subsection{Analysis of Surface Water-Groundwater Exchange}

The water exchange between the river and aquifer can be quantitatively expressed by Darcy's law, namely

$$
Q=K W L \frac{H_{R}-H}{M}
$$

where $L$ is the stream length $[\mathrm{L}], W$ is the stream width $[\mathrm{L}], M$ is the thickness of riverbed sediment $[\mathrm{L}], K$ is the hydraulic conductivity $[\mathrm{L} / \mathrm{T}]$ of the stream sediments, $H_{\mathrm{R}}$ is the river level [L], $H$ is the groundwater level near river $[\mathrm{L}]$, and $Q$ is the quantity of recharge and discharge of groundwater $\left[\mathrm{L}^{3} / \mathrm{T}\right]$. When the river level is higher than the groundwater level of the aquifer, the value of $Q$ is larger than 0 , indicating that the ground water is recharged by the surface water. In contrast, the groundwater discharges from the aquifer to the river.

\subsection{Analysis of the Migration Time of Pollution}

When the groundwater velocity is calculated, the migration time of pollution in the groundwater can be estimated, according to the distance between the monitoring wells and the river. The equation for calculating the groundwater velocity $V[\mathrm{~L} / \mathrm{T}]$ is expressed as

$$
V=K\left(H_{R}-H\right) / L_{1}
$$

where $L_{1}$ is the distance between the river and well [L].

Then, the actual flow velocity $u[\mathrm{~L} / \mathrm{T}]$ can be calculated as

$$
u=V / n_{e},
$$

where the effective porosity $n_{\mathrm{e}}[-]$ can be expressed as

$$
n_{e}=\frac{n}{1-n}
$$

where $n$ is the porosity [-].

Then, the migration time of pollution from the river water to groundwater $t[\mathrm{~T}]$ can be estimated

$$
t=L / u
$$

\section{Results and Discussion}

\subsection{Groundwater and Surface Water Interactions}

The drilling data of the thirteen monitoring wells show that there is a low permeable layer at the bottom of Luanhe river. The stream and multi-layered aquifer system can exchange water through the thin layer with low permeable material. Figure 3 shows the variations of the groundwater level observed in the wells and the stream level on the cross sections A-A', B-B' and C-C', respectively. One can see that the observed groundwater level in the wells and stream level varied with seasons. During the dry season from November 2010 to April 2011, the observed groundwater level decreased slightly and the groundwater discharged to the river. Then, the groundwater level exhibited a gradually increasing trend from May to September 2011 during the period of river stage rise. In addition, from Figure 2, one can see that there are cones of groundwater depression in the vicinity of wells W2, W7 and W12, because there are a large number of wells for civil use with an amount of pumping more than 10 thousand $\mathrm{m}^{3}$ per day. Figure 4 shows the contour map of the average groundwater level in the study area. The groundwater level decreases from the section A-A' to section B-B'. This indicates that the groundwater flow direction is from north to south, which is basically consistent with that of the river water. 


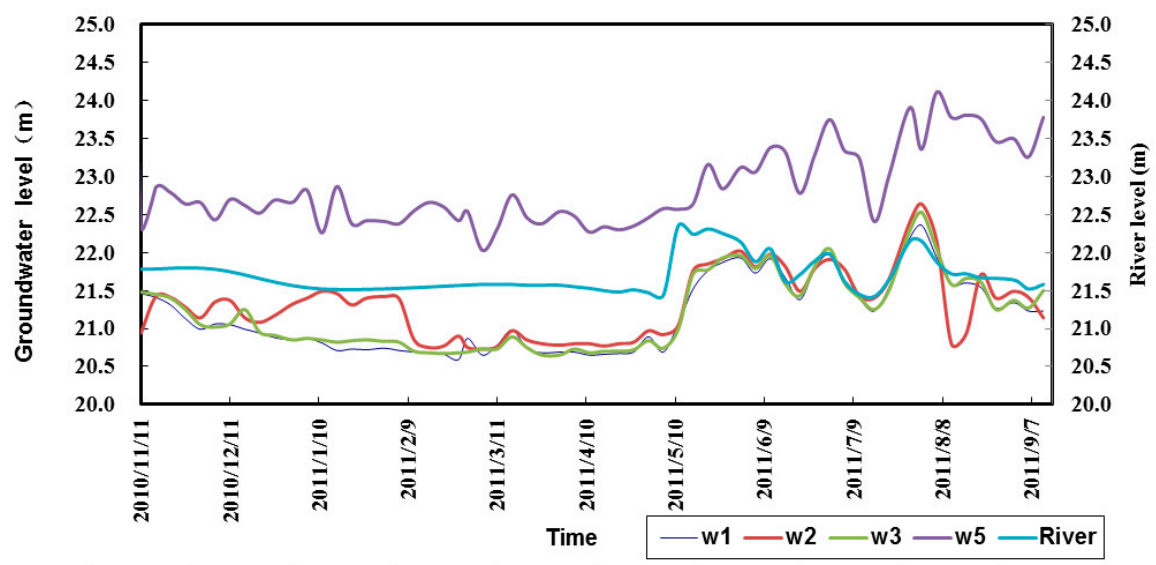

(a)

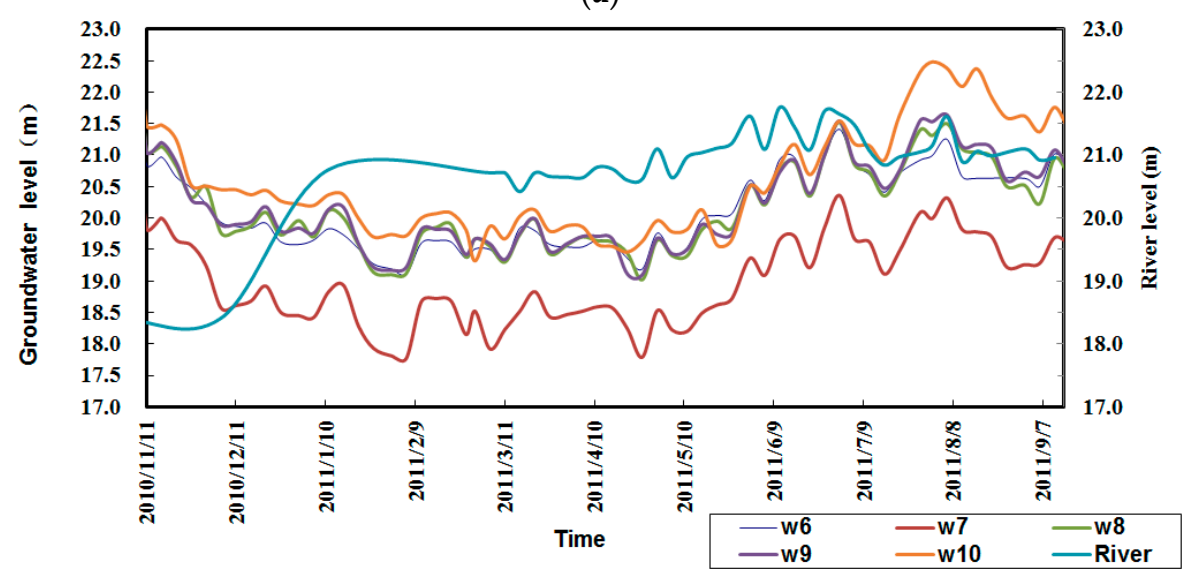

(b)

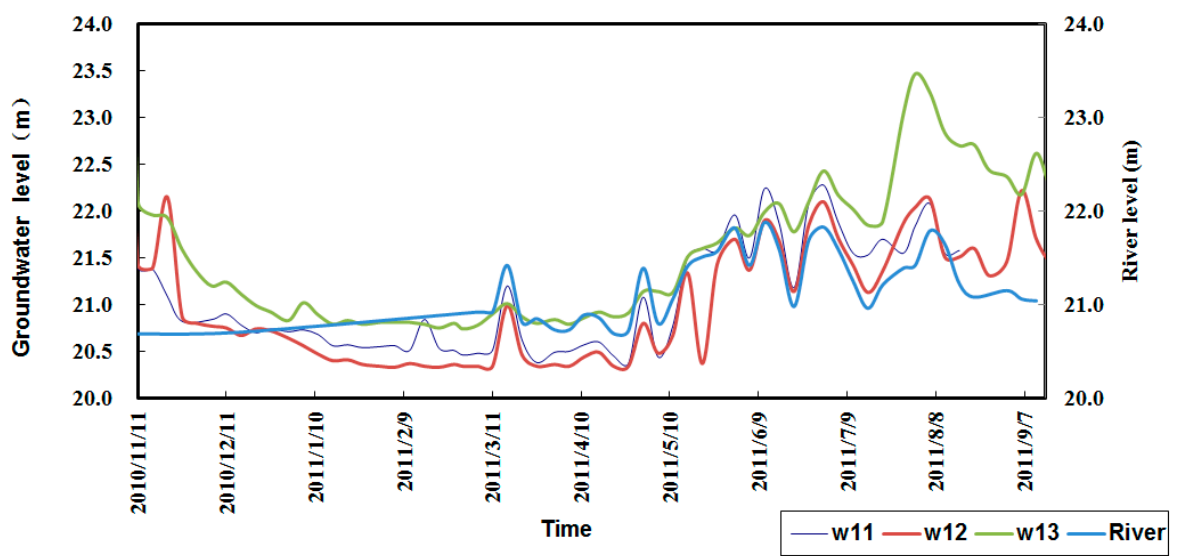

(c)

Figure 3. Temporal variations of the groundwater level observed in the wells along (a) transect $A-A^{\prime}$, (b) transect B-B' and (c) transect $C-C^{\prime}$, respectively. 


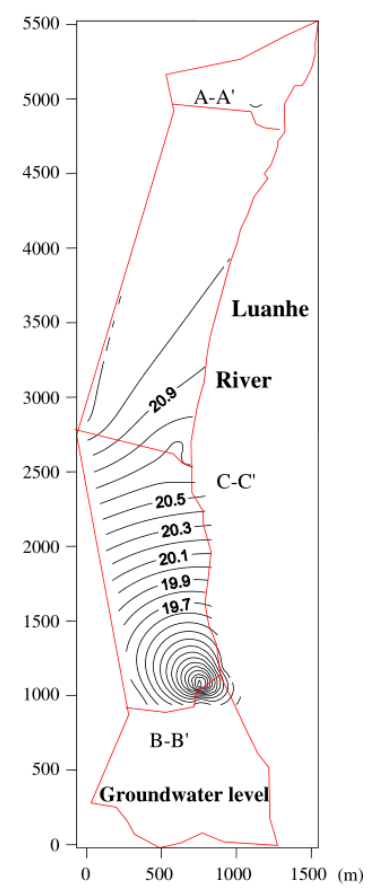

Figure 4. Contour map of the average groundwater level in the study area, where the red lines represent the zone of the study area and the cross-sections, and the black lines represent the average groundwater level.

In order to investigate the interaction between river water and groundwater, the quantity of recharge from the river water to groundwater and that of discharge from groundwater to river water were calculated, based on the equation (1). Although groundwater flow paths in the riparian areas can be significantly more complex than simple vertical fluxes [38,39], it is still useful to compare river level with nearby groundwater level to determine if the reach is likely to be gaining or losing water $[40,41]$. The hydraulic conductivity of riverbed sediment was estimated to be $0.032 \mathrm{~m} / \mathrm{d}$ based on the field test. The total length of the calculated river reach is $5.5 \mathrm{~km}$. The length of each section was determined according to the distribution of seepage field. The calculated width is equal to half of the width of river, considering the symmetry. Based on the field investigation, the thickness of the bottom sediment is $0.6 \mathrm{~m}, 0.7 \mathrm{~m}$ and $0.8 \mathrm{~m}$ for the sections $\mathrm{A}-\mathrm{A}^{\prime}, \mathrm{B}-\mathrm{B}^{\prime}$ and $\mathrm{C}-\mathrm{C}^{\prime}$, respectively. The river level is the level corresponding to each section. The groundwater level is equal to nearby groundwater level in each section (well 1 for section A-A', well 11 for section $C-C^{\prime}$ and well 6 for section B-B'). Therefore, the amount of recharge and discharge is estimated based on the river level and groundwater level according to the Darcy's law. The amount of recharge and discharge in different sections are shown in Figure 5. From the figure, one can see that the river water recharges groundwater during most of time from November 2010 to September 2011. The amount of groundwater supplied by the river is $346.3 \times 10^{4} \mathrm{~m}^{3} / \mathrm{a}$, and the discharge of groundwater to the river is about $14.08 \times 10^{4} \mathrm{~m}^{3} / \mathrm{a}$ during this period (Table 2). 


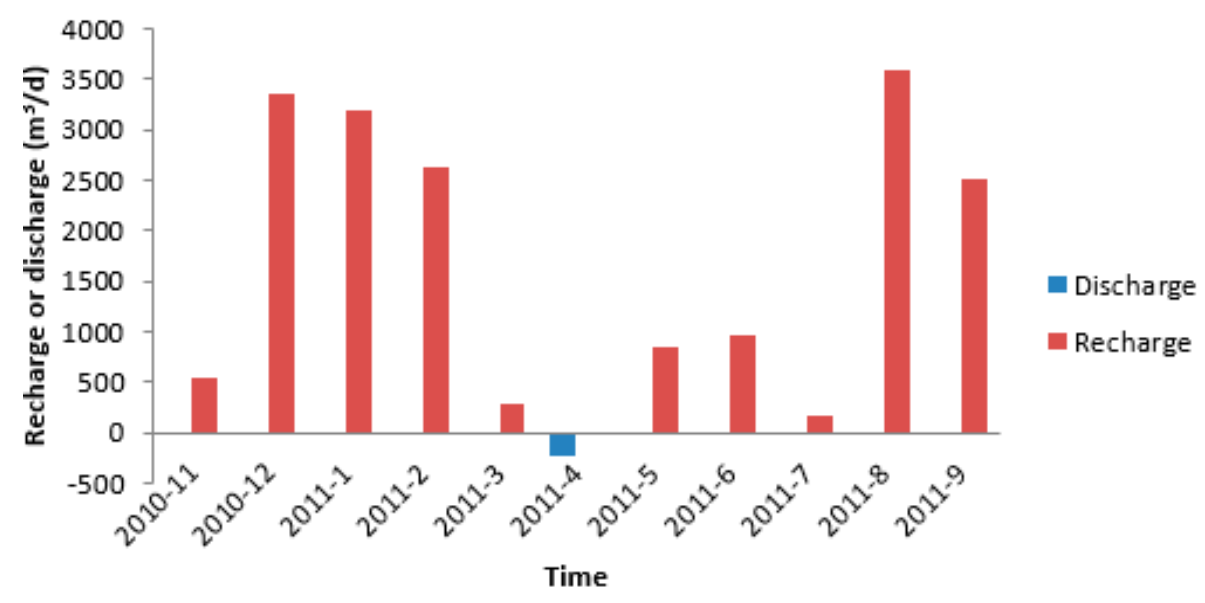

(a)

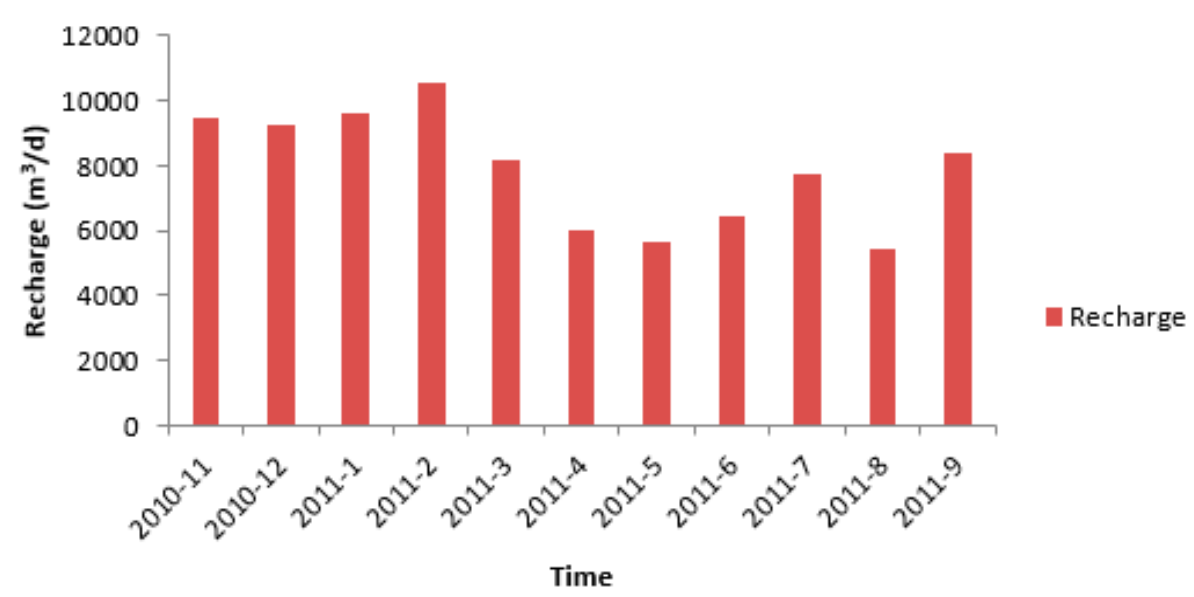

(b)

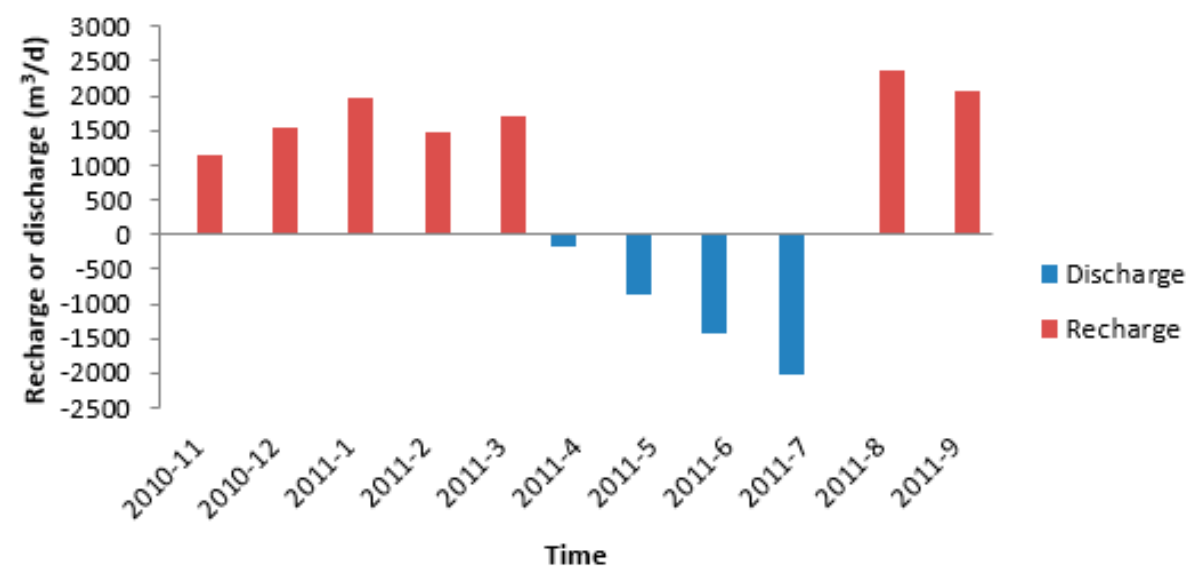

(c)

Figure 5. The amount of recharge and discharge in different sections (a) transect A-A', (b) transect B-B', and (c) transect C-C'. 
Table 2. Total recharge and discharge of groundwater in the study area $\left(10^{4} \mathrm{~m}^{3} / \mathrm{a}\right)$.

\begin{tabular}{ccccc}
\hline $\begin{array}{c}\text { Recharge and } \\
\text { Discharge }\end{array}$ & $\begin{array}{c}\text { The Section of } \\
\text { A-A }\end{array}$ & $\begin{array}{c}\text { The Section of } \\
\text { B-B' }\end{array}$ & $\begin{array}{c}\text { The Section of } \\
\text { C-C }\end{array}$ & $\begin{array}{c}\text { Total Recharge } \\
\text { and Discharge of } \\
\text { Groundwater }\end{array}$ \\
\hline $\begin{array}{c}\text { Recharge } \\
\text { Discharge }\end{array}$ & 54.29 & 259.89 & 32.13 & 346.3 \\
\hline
\end{tabular}

\subsection{Chemistry and Nitrate of Groundwater}

The total dissolved solids (TDS), $\mathrm{pH}$, electrical conductivity, temperature and nitrate concentration measured in the groundwater and surface water are shown in Table 3 . The electrical conductivity (EC), which is an indirect measure of TDS, varies between 477 and $1844 \mu \mathrm{S} / \mathrm{cm}$ with an average of $972 \mu \mathrm{S} / \mathrm{cm}$ (Table 3). In general, the samples are slightly alkaline with $\mathrm{pH}$ values ranging between 7.0 and 8.5. The temperature of surface water samples ranges from $2.9{ }^{\circ} \mathrm{C}$ to $26.7^{\circ} \mathrm{C}$, and that of groundwater samples is between $9.9^{\circ} \mathrm{C}$ and $18.6^{\circ} \mathrm{C}$. TDS values range from as low as $294 \mathrm{mg} / \mathrm{L}$ to a maximum of $1500 \mathrm{mg} / \mathrm{L}$ with an average of $629 \mathrm{mg} / \mathrm{L}$.

Table 3. Summary of physical and chemical data obtained for surface and groundwater samples in the study area.

\begin{tabular}{|c|c|c|c|c|c|c|c|c|}
\hline No. & $\begin{array}{l}\text { Sampling } \\
\text { Date }\end{array}$ & $\mathrm{pH}$ & Temp ${ }^{\circ} \mathrm{C}$ & $\begin{array}{c}\mathrm{EC} \\
(\mu \mathrm{S} / \mathrm{cm})\end{array}$ & $\begin{array}{l}\text { TDS } \\
(\mathrm{mg} / \mathrm{L})\end{array}$ & \multicolumn{2}{|c|}{$\mathrm{NO}_{3}{ }^{-}\left(\mathrm{mg} / \mathrm{L} \Phi^{15} \mathrm{~N}(\% 0)\right.$} & $\delta^{18} \mathrm{O}(\%)$ \\
\hline \multirow{6}{*}{ W1 } & $11 / 8 / 2010$ & - & 17.2 & 1102 & 630 & 17.3 & - & - \\
\hline & $1 / 11 / 2011$ & 7.4 & 14.0 & 1126 & 692 & 17.9 & 10.9 & - \\
\hline & $3 / 5 / 2011$ & 7.4 & 12.2 & 1282 & 866 & 29.3 & 11.0 & - \\
\hline & $5 / 11 / 2011$ & 7.6 & 14.4 & 822 & 524 & 8.37 & - & - \\
\hline & $7 / 12 / 2011$ & 8.0 & 15.7 & 847 & 536 & 4.18 & 43.12 & - \\
\hline & $9 / 15 / 2011$ & 8.0 & 18.6 & 857 & 698 & 14.4 & 32.22 & -6.34 \\
\hline \multirow[t]{6}{*}{ W2 } & $11 / 8 / 2010$ & - & 14.0 & 686 & 382 & 8.3 & - & - \\
\hline & $1 / 11 / 2011$ & 7.6 & 13.3 & 605 & 356 & 6.3 & 12.0 & - \\
\hline & $3 / 5 / 2011$ & 7.7 & 12.0 & 552 & 316 & 6.07 & 9.4 & - \\
\hline & $5 / 11 / 2011$ & 7.7 & 16.4 & 637 & 448 & 5.96 & - & - \\
\hline & $7 / 12 / 2011$ & 7.9 & 18.4 & 683 & 436 & 5.14 & 81.83 & - \\
\hline & $9 / 15 / 2011$ & 8.0 & 17.4 & 513 & 430 & 6.58 & 25.57 & -7.16 \\
\hline \multirow[t]{6}{*}{ W3 } & $11 / 8 / 2010$ & - & 14.2 & 1443 & 878 & 47.0 & - & - \\
\hline & $1 / 11 / 2011$ & 7.4 & 9.9 & 1327 & 940 & 41.6 & - & - \\
\hline & $3 / 5 / 2011$ & 7.5 & 13.1 & 989 & 612 & 17 & - & - \\
\hline & $5 / 11 / 2011$ & 7.6 & 13.9 & 996 & 578 & 18.4 & - & - \\
\hline & $7 / 12 / 2011$ & 7.8 & 16.7 & 950 & 638 & 19.1 & 139.0 & - \\
\hline & $9 / 15 / 2011$ & 7.8 & 15.7 & 1122 & 956 & 28.2 & 19.88 & -7.34 \\
\hline \multirow[t]{6}{*}{ W5 } & $11 / 8 / 2010$ & - & 13.5 & 639 & 378 & 7.98 & - & - \\
\hline & $1 / 11 / 2011$ & 8.5 & 11.5 & 572 & 388 & 6.45 & - & - \\
\hline & $3 / 5 / 2011$ & 7.7 & 12.3 & 634 & 382 & 7.36 & - & - \\
\hline & $5 / 11 / 2011$ & 7.8 & 14.1 & 477 & 548 & 4.24 & - & - \\
\hline & $7 / 12 / 2011$ & 7.9 & 14.6 & 586 & 390 & 4.8 & - & - \\
\hline & $9 / 15 / 2011$ & 7.9 & 15.1 & 675 & 522 & 6.97 & - & - \\
\hline \multirow[t]{6}{*}{ W6 } & $11 / 8 / 2010$ & - & 17.4 & 600 & 294 & 0.97 & - & - \\
\hline & $1 / 11 / 2011$ & 7.5 & 14.1 & 722 & 466 & 6.45 & 12.1 & - \\
\hline & $3 / 5 / 2011$ & 7.8 & 12.0 & 762 & 430 & 7.36 & 7.3 & - \\
\hline & $5 / 11 / 2011$ & 7.8 & 10.3 & 800 & 624 & 0.99 & - & - \\
\hline & $7 / 12 / 2011$ & 7.8 & 16.5 & 717 & 462 & 0.09 & - & - \\
\hline & $9 / 15 / 2011$ & 7.8 & 17.4 & 752 & 540 & 1.0 & 13.0 & -6.73 \\
\hline
\end{tabular}


Table 3. Cont

\begin{tabular}{|c|c|c|c|c|c|c|c|c|}
\hline No. & $\begin{array}{c}\text { Sampling } \\
\text { Date }\end{array}$ & $\mathrm{pH}$ & $\operatorname{Temp}{ }^{\circ} \mathrm{C}$ & $\begin{array}{c}\text { EC } \\
(\mu \mathrm{S} / \mathrm{cm})\end{array}$ & $\begin{array}{c}\text { TDS } \\
(\mathrm{mg} / \mathrm{L})\end{array}$ & \multicolumn{2}{|c|}{$\mathrm{NO}_{3}{ }^{-}\left(\mathrm{mg} / \mathrm{L} \Phi^{15} \mathrm{~N}(\% 0)\right.$} & $\delta^{18} \mathrm{O}(\%)$ \\
\hline \multirow[t]{6}{*}{ W7 } & $11 / 8 / 2010$ & - & 14.9 & 763 & 396 & 4.0 & - & - \\
\hline & 1/11/2011 & 7.3 & 12.1 & 1320 & 868 & 33.3 & 3.8 & - \\
\hline & $3 / 5 / 2011$ & 7.9 & 13.6 & 829 & 432 & 4.26 & 10.7 & - \\
\hline & $5 / 11 / 2011$ & 7.8 & 12.5 & 700 & 498 & 2.61 & - & - \\
\hline & 7/12/2011 & 7.9 & 13.2 & 600 & 408 & $<\mathrm{DL}$ & - & - \\
\hline & 9/15/2011 & 7.9 & 15.5 & 624 & 450 & 0.87 & 10.7 & -7.66 \\
\hline \multirow[t]{6}{*}{ W8 } & $11 / 8 / 2010$ & - & 14.2 & 939 & 420 & 23.7 & - & - \\
\hline & 1/11/2011 & 7.5 & 10.3 & 914 & 524 & 24.6 & 7.8 & - \\
\hline & $3 / 5 / 2011$ & 7.7 & 12.7 & 834 & 444 & 15 & 6.4 & - \\
\hline & $5 / 11 / 2011$ & 7.7 & 12.4 & 816 & 524 & 16.6 & - & - \\
\hline & $7 / 12 / 2011$ & 7.7 & 13.1 & 987 & 576 & 24.1 & 21.06 & - \\
\hline & $9 / 15 / 2011$ & 7.8 & 16.5 & 1152 & 794 & 30.5 & 21.06 & -7.37 \\
\hline \multirow[t]{6}{*}{ W9 } & $11 / 8 / 2010$ & - & 14.8 & 1198 & 590 & 42.6 & - & - \\
\hline & 1/11/2011 & 7.5 & 11.5 & 747 & 538 & 13 & 6.3 & - \\
\hline & $3 / 5 / 2011$ & 7.7 & 12.6 & 722 & 490 & 11.4 & 6.3 & - \\
\hline & $5 / 11 / 2011$ & 7.2 & 14.0 & 665 & 410 & 6.83 & - & - \\
\hline & $7 / 12 / 2011$ & 7.7 & 14.3 & 859 & 546 & 19.0 & 15.17 & - \\
\hline & $9 / 15 / 2011$ & 7.8 & 17.0 & 1109 & 880 & 30.4 & 49.78 & -6.74 \\
\hline \multirow[t]{6}{*}{ W10 } & $11 / 8 / 2010$ & - & 16.1 & 1224 & 692 & 20.2 & - & - \\
\hline & $1 / 11 / 2011$ & 7.3 & 11.0 & 1844 & 1500 & 60.3 & 9.6 & - \\
\hline & $3 / 5 / 2011$ & 7.4 & 12.7 & 1736 & 792 & 56.1 & 50.4 & - \\
\hline & 5/11/2011 & 7.5 & 11.9 & 1766 & 1120 & 58.0 & - & - \\
\hline & $7 / 12 / 2011$ & 7.5 & 13.8 & 1605 & 1420 & 47.9 & 21.57 & - \\
\hline & $9 / 15 / 2011$ & 7.7 & 12.8 & 1383 & 820 & 34.7 & 4.79 & -7.4 \\
\hline \multirow[t]{6}{*}{ W11 } & $11 / 8 / 2010$ & - & 15.8 & 1131 & 576 & 28.7 & - & - \\
\hline & 1/11/2011 & 7.5 & 11.4 & 1342 & 948 & 34.9 & 9.8 & - \\
\hline & $3 / 5 / 2011$ & 7.4 & 12.0 & 1304 & 1100 & 31.4 & 10.8 & - \\
\hline & $5 / 11 / 2011$ & 7.8 & 13.2 & 860 & 536 & 9.6 & - & - \\
\hline & $7 / 12 / 2011$ & 8.0 & 13.8 & - & 536 & 9.6 & 98.27 & - \\
\hline & 9/15/2011 & 8.0 & 15.7 & - & 698 & 9.6 & 48.0 & -7.4 \\
\hline \multirow[t]{6}{*}{ W12 } & $11 / 8 / 2010$ & - & 15.9 & 1265 & 726 & 17.7 & - & - \\
\hline & $1 / 11 / 2011$ & 7.4 & 13.8 & 1026 & 626 & 18.6 & 10.2 & - \\
\hline & $3 / 5 / 2011$ & 7.4 & 15.1 & 1129 & 615 & 24.1 & 8.8 & - \\
\hline & $5 / 11 / 2011$ & 7.4 & 14.7 & 1133 & 732 & 24.9 & - & - \\
\hline & 7/12/2011 & 7.5 & 14.8 & 1145 & 822 & 22.3 & 18.9 & - \\
\hline & 9/15/2011 & 7.6 & 16.7 & 1086 & 870 & 20.4 & 31.42 & -7.39 \\
\hline \multirow[t]{6}{*}{ W13 } & $11 / 8 / 2010$ & - & 16.3 & 1610 & 856 & 17.2 & - & - \\
\hline & $1 / 11 / 2011$ & 7.0 & 14.9 & 1728 & 1120 & 13 & 11.1 & - \\
\hline & $3 / 5 / 2011$ & 7.2 & 13.4 & 1765 & 1180 & 24.6 & 15.2 & - \\
\hline & $5 / 11 / 2011$ & 7.2 & 15.1 & 1310 & 802 & 23.1 & - & - \\
\hline & $7 / 12 / 2011$ & 7.5 & 15.8 & 1412 & 920 & 13 & - & - \\
\hline & $9 / 15 / 2011$ & 7.4 & 15.0 & 1615 & 1090 & 1.83 & 15.2 & -7.3 \\
\hline River & $11 / 8 / 2010$ & 7.5 & 12.7 & 694 & 434 & 6.37 & - & - \\
\hline \multirow[t]{5}{*}{ A-A } & 1/11/2011 & 7.6 & 13.0 & 649 & 406 & 6.88 & 8.9 & - \\
\hline & $3 / 5 / 2011$ & 7.4 & 6.2 & 659 & 412 & 6.11 & 7.3 & - \\
\hline & $5 / 11 / 2011$ & 7.4 & 18.5 & 854 & 534 & 5.36 & - & - \\
\hline & $7 / 12 / 2011$ & 7.8 & 25.6 & 544 & 340 & 3.34 & 120.11 & - \\
\hline & 9/15/2011 & 8.0 & 23.2 & 934 & 584 & 4.41 & 30.12 & -6.5 \\
\hline River & 11/8/2010 & 7.7 & 11.0 & 675 & 422 & 6.48 & - & - \\
\hline \multirow[t]{5}{*}{ B-B } & $1 / 11 / 2011$ & 7.8 & 2.9 & 656 & 410 & 5.79 & 7.2 & - \\
\hline & $3 / 5 / 2011$ & 7.6 & 6.3 & 638 & 399 & 6.15 & 22.3 & - \\
\hline & $5 / 11 / 2011$ & 7.5 & 19.4 & 656 & 410 & 4.92 & - & - \\
\hline & $7 / 12 / 2011$ & 7.7 & 26.7 & 1002 & 626 & $<\mathrm{DL}$ & 7.2 & - \\
\hline & $9 / 15 / 2011$ & 7.8 & 23.4 & 1037 & 648 & 3.01 & 22.3 & -7.4 \\
\hline
\end{tabular}


Table 3 shows that nitrate concentration is spatially and temporally variable. Three typical two-dimensional profiles of A-A', B-B' and C-C' were selected to study the nitrate variation in groundwater and surface water in different months. Figure 6a shows the variations in nitrate concentrations of groundwater and surface water in the transect $\mathrm{A}-\mathrm{A}^{\prime}$. The nitrate concentration of surface water varied through time from $3.34 \mathrm{mg} / \mathrm{L}$ to $6.88 \mathrm{mg} / \mathrm{L}$. The nitrate concentrations of surface water were higher from November 2010 to March 2011 than those sampled during the months from May to September 2011. The river level rises in May 2011, because the upstream sluice was open and the river water was released. This suggests that the nitrate concentration was diluted by the river water flow from May 2011. For groundwater samples at wells W1-3, nitrate concentration changes very large with time ranging from $4.18 \mathrm{mg} / \mathrm{L}$ to $41.6 \mathrm{mg} / \mathrm{L}$. Compared with the nitrate concentration of groundwater in wells far from the river, the nitrate concentration of river water was lower, indicating that the pollution of river water has little influence on groundwater far from the river. The nitrate concentration in well W1 was affected by the river level, because it is near the river. The observed nitrate concentration increased from $17.3 \mathrm{mg} / \mathrm{L}$ to $29.3 \mathrm{mg} / \mathrm{L}$ when the groundwater level was lower than the river level, and then decreaseed to $4.18 \mathrm{mg} / \mathrm{L}$ as the groundwater level increased from November 2010 to July 2011. Then, it tended to increase slowly from July to September 2011. The nitrate concentration in well W2 as lower than that of well W1. This may be due to the long-term pumping of groundwater in well W2. For W3, the nitrate concentration decreased from $47 \mathrm{mg} / \mathrm{L}$ to $17 \mathrm{mg} / \mathrm{L}$ over the period from November 2010-March 2011, and then increased to $28.2 \mathrm{mg} / \mathrm{L}$ in September 2011. Generally, the nitrate concentrations of groundwater in the transect A- $\mathrm{A}^{\prime}$ were low from May to July of 2011, because the groundwater level rises as the rainfall increases during this period, which make the nitrate in the aquifer diluted.

Compared with Figure 6a, in Figure 6b, one can see that the variation in nitrate concentrations of surface water in the transect A-A' was similar to those of surface water in the transect B-B'. Nitrate concentrations of surface water varied little over time, ranging from $0.07 \mathrm{mg} / \mathrm{L}$ to $6.48 \mathrm{mg} / \mathrm{L}$. However, the nitrate concentrations of surface water in the transect $B-B^{\prime}$ were lower than those of the surface water in transect A- $\mathrm{A}^{\prime}$. This can be attributed to the different structure of aquifer of these two transects. This was mainly due to the large particle size of soil in the transect A- $\mathrm{A}^{\prime}$ compared with that of transect B-B' (Figure 2). Therefore, the velocity of groundwater flow in the transect $A-A^{\prime}$ is faster than that in the transect $B-\mathrm{B}^{\prime}$. As a result, the nitrate in groundwater is easily discharged to the river water in the transect $A-A^{\prime}$. Figure $6 \mathrm{~b}$ shows that the nitrate concentration of groundwater undergoes large changes through time ranging from $0.07 \mathrm{mg} / \mathrm{L}$ to $60.3 \mathrm{mg} / \mathrm{L}$ in the transect B-B'. Similar to the well W1, the well W6 near the river is also affected by the river water, and the nitrate concentration variation is basically the same as that of the river. The nitrate concentration increased from $0.97 \mathrm{mg} / \mathrm{L}$ to $7.36 \mathrm{mg} / \mathrm{L}$, and then decreased to $0.09 \mathrm{mg} / \mathrm{L}$ as the groundwater level increased from November 2010 to July 2011. It increased to $1 \mathrm{mg} / \mathrm{L}$ slowly from July to September 2011. The variation in nitrate concentration of well W7 is basically consistent with that of the river water in the transect B-B'; however, it was lower than that of the river water during the period of November 2010-March 2011. This was mainly due to the groundwater pumping for drinking near well W7. In particular, the nitrate concentration in well W7 was lower than the detection limit in July 2011, which was assumed to be $0 \mathrm{mg} / \mathrm{L}$. For the sampling well W8, the nitrate concentration increased from $23.7 \mathrm{mg} / \mathrm{L}$ to $24.6 \mathrm{mg} / \mathrm{L}$, and decreased to be $15.0 \mathrm{mg} / \mathrm{L}$ from November 2010 to March2011. Then, it continued to increase, reaching a maximum value of $30.5 \mathrm{mg} / \mathrm{L}$ in September 2011. The variation trend of nitrate concentration in well W9 was similar to that in well W8. It decreased from $42.6 \mathrm{mg} / \mathrm{L}$ to $6.83 \mathrm{mg} / \mathrm{L}$, and then increased to $30.4 \mathrm{mg} / \mathrm{L}$ from November 2010 to September 2011. The nitrate concentration in well W10 showed considerable variation, ranging from $20.2 \mathrm{mg} / \mathrm{L}$ to $60.3 \mathrm{mg} / \mathrm{L}$. During the period of January-July 2011, the nitrate concentration as above the national drinking water standards $(45 \mathrm{mg} / \mathrm{L})$ in China. The nitrate concentrations in well W8-10 were greater than those of well W6-7. This was mainly due to the fact that the observation well W8-9 are located in farmland, and the surface fertilization results in higher nitrate concentrations in the wells. For well W10, it might be due to the discharge of domestic sewage, because it is located near a village. 


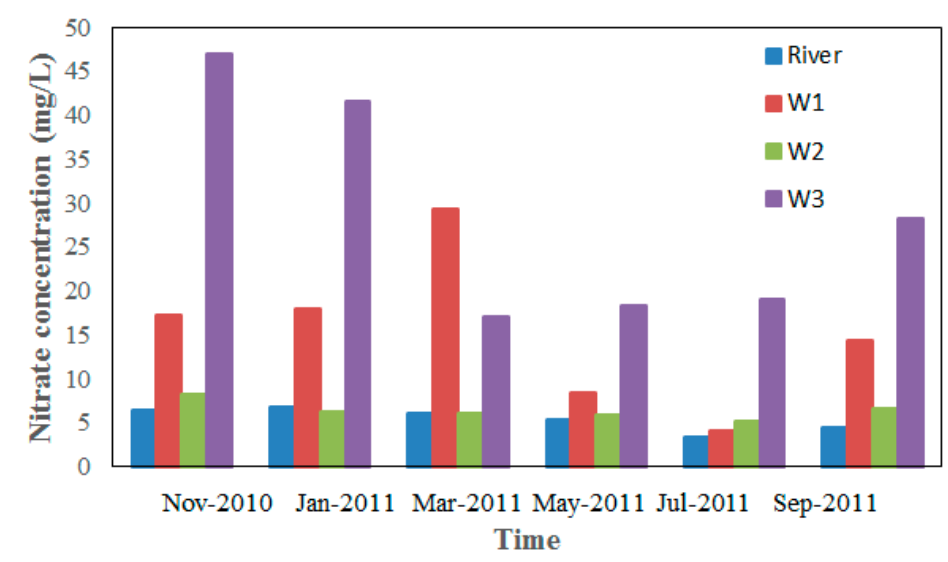

(a)

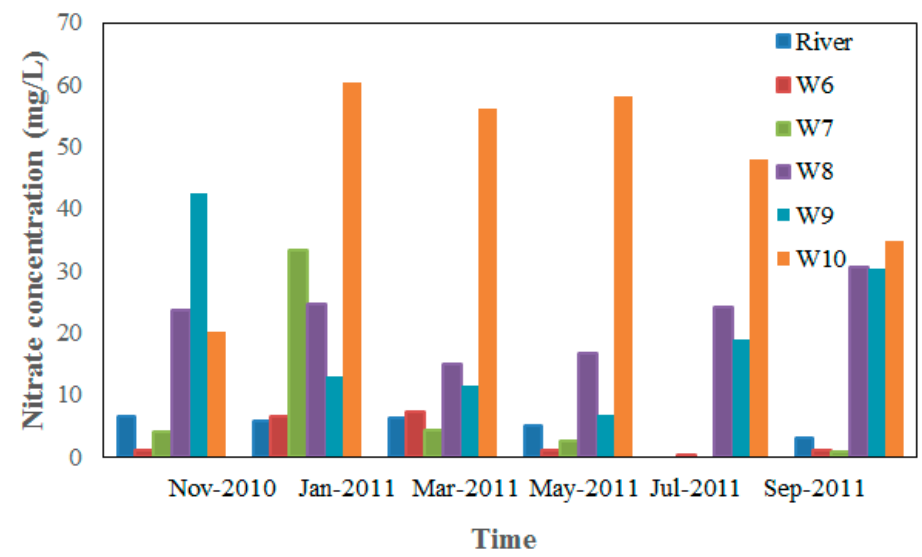

(b)

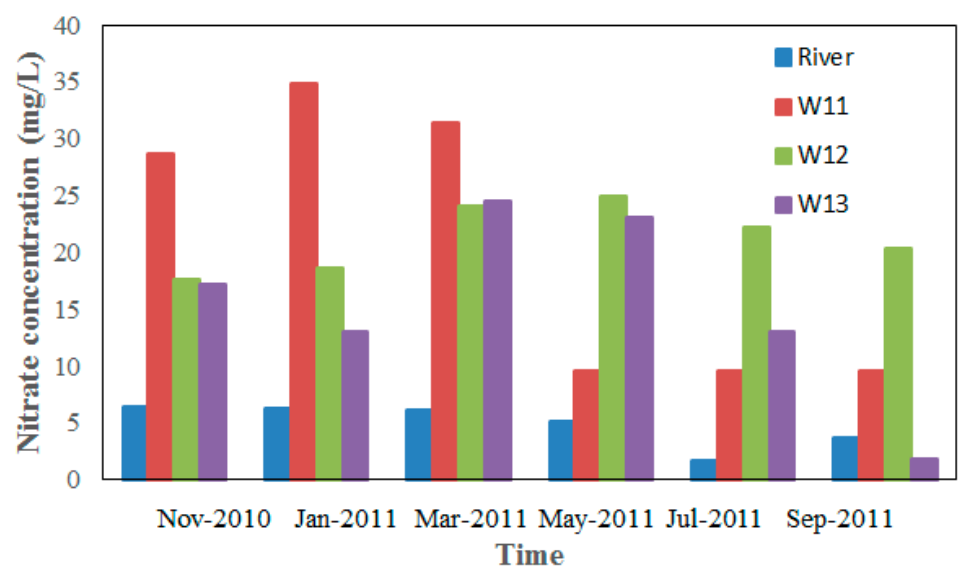

(c)

Figure 6. Nitrate concentration of groundwater and surface water for different transects, (a) A-A', (b) $B-B^{\prime}$ and (c) C-C'.

The nitrate concentration in the river water of the $C-C^{\prime}$ section is the average value of nitrate concentration in the A- $\mathrm{A}^{\prime}$ section and that in the B-B' section, because the $C-\mathrm{C}^{\prime}$ section is located between the A-A' section and B-B' section. Figure $6 \mathrm{c}$ shows that the variation in nitrate concentrations of surface water in the transect C-C' changes from $1.67 \mathrm{mg} / \mathrm{L}$ to $6.43 \mathrm{mg} / \mathrm{L}$. The nitrate concentration is higher when the river level is low; however, it is lower when the river level is high. This indicates that the nitrate concentration is diluted as the increasing of river water, and the nitrate source of river water is related to the pollution of surface water. From Figure $6 c$, one can see that the nitrate concentration of 
groundwater changes considerably over time, with values ranging between $1.83 \mathrm{mg} / \mathrm{L}$ and $34.9 \mathrm{mg} / \mathrm{L}$ in the transect C-C'. The nitrate concentration in well W11 increased from $28.7 \mathrm{mg} / \mathrm{L}$ to $34.9 \mathrm{mg} / \mathrm{L}$, and then decreased to be $9.6 \mathrm{mg} / \mathrm{L}$ from November 2010 to September 2011. However, there is no observed data in well W11 after May 2011, because the well was scrapped. For well W12, the nitrate concentration firstly increased from $17.7 \mathrm{mg} / \mathrm{L}$ to $24.9 \mathrm{mg} / \mathrm{L}$, and then decreased to $20.4 \mathrm{mg} / \mathrm{L}$ from November 2010 to September 2011. The nitrate concentration in well W13 decreased from $17.2 \mathrm{mg} / \mathrm{L}$ to $13 \mathrm{mg} / \mathrm{L}$, and then increased to a maximum value of $24.6 \mathrm{mg} / \mathrm{L}$ in March 2011. Finally, it decreased to $1.83 \mathrm{mg} / \mathrm{L}$ from March to September 2011.

\subsection{Nitrate Sources}

The nitrate in river water and groundwater mainly comes from atmospheric deposition, inorganic fertilizers, soil, livestock manure and sewage. The nitrate from different sources has different isotopic ranges, and the nitrate source can be judged according to the value of $\delta^{15} \mathrm{~N}-\mathrm{NO}_{3}$ in groundwater. The $\delta^{15} \mathrm{~N}-\mathrm{NO}_{3}$ values for atmospheric nitrogen deposition ranges from $-13 \%$ to $13 \%$ [20,22]. Nitrate originating from synthetic fertilizers and natural soil organic matter is characterized by $\delta^{15} \mathrm{~N}^{-\mathrm{NO}_{3}}$ values ranging from $-4 \%$ to $4 \%$ and from $4 \%$ to $8 \%$, respectively, which is distinct from nitrogen in sewage (8\%o 15\%o) and livestock manure $(10 \%$ 22\%o) [42-44]. Combined with the hydrogeological condition of the study area, the nitrate source of groundwater and river water can be deduced based on the values of $\delta^{15} \mathrm{~N}-\mathrm{NO}_{3}$. However, despite its effectiveness, nitrate sources cannot be identified by the $\delta^{15} \mathrm{~N}$ signature alone due to the $\delta^{15} \mathrm{~N}$ overlapping ranges and the occurrence of nitrate isotopic fractionation $[19,45]$. The relationship between the two isotopes $\left(\delta^{15} \mathrm{~N}-\mathrm{NO}_{3}\right.$ and $\left.\delta^{18} \mathrm{O}-\mathrm{NO}_{3}\right)$ can be further used to judge the nitrate source of groundwater and river water $[46,47]$.

The values of ${ }^{18} \mathrm{O}$ and ${ }^{15} \mathrm{~N}$ are listed in Table 3. The average standard deviation of normalized data is $0.3 \%$ for $\delta^{15} \mathrm{~N}$. Isotopic composition of nitrate in groundwater and river water showed seasonal variation. The range of $\delta^{15} \mathrm{~N}-\mathrm{NO}_{3}$ values was from 3.8 to $139 \%$ for groundwater and from 7.2 to $120.1 \%$ for surface water, showing a large variance. The maximum $\delta^{15} \mathrm{~N}-\mathrm{NO}_{3}$ value of $120.1 \%$ occurred at surface water in the transect $\mathrm{A}-\mathrm{A}^{\prime}$ in July 2011, when the river $\mathrm{NO}_{3}-\mathrm{N}$ concentration was at its minimum. The $\delta^{18} \mathrm{O}-\mathrm{NO}_{3}$ values ranged from $-7.66 \%$ to $-6.34 \%$ for groundwater and from $-7.4 \%$ to $-6.5 \%$ for surface water, with the mean values of $-7.15 \%$ for groundwater and $-6.95 \%$ for surface water. The highest $\delta^{18} \mathrm{O}-\mathrm{NO}_{3}$ value occurred at well $\mathrm{W} 1$ in September $2011(-6.34 \%$ ), while the lowest value $\left(-7.66 \%\right.$ of $\delta^{18} \mathrm{O}^{-\mathrm{NO}_{3}}$ was obtained at well W7. As can be seen from Figure 7, there was a tendency for both $\delta^{15} \mathrm{~N}-\mathrm{NO}_{3}$ and $\delta^{18} \mathrm{O}-\mathrm{NO}_{3}$ to increase with N-NO 3 concentration. According to the bi-plot of $\delta^{15} \mathrm{~N}-\mathrm{NO}_{3}$ versus $\delta^{18} \mathrm{O}-\mathrm{NO}_{3}$ for potential nitrate sources, the isotopic signatures of nitrate in groundwater and river water fall within the window for sewage, livestock manure and natural soil organic matter (Figure 8). This indicates that a significant positive relationship was discernable for the whole dataset.

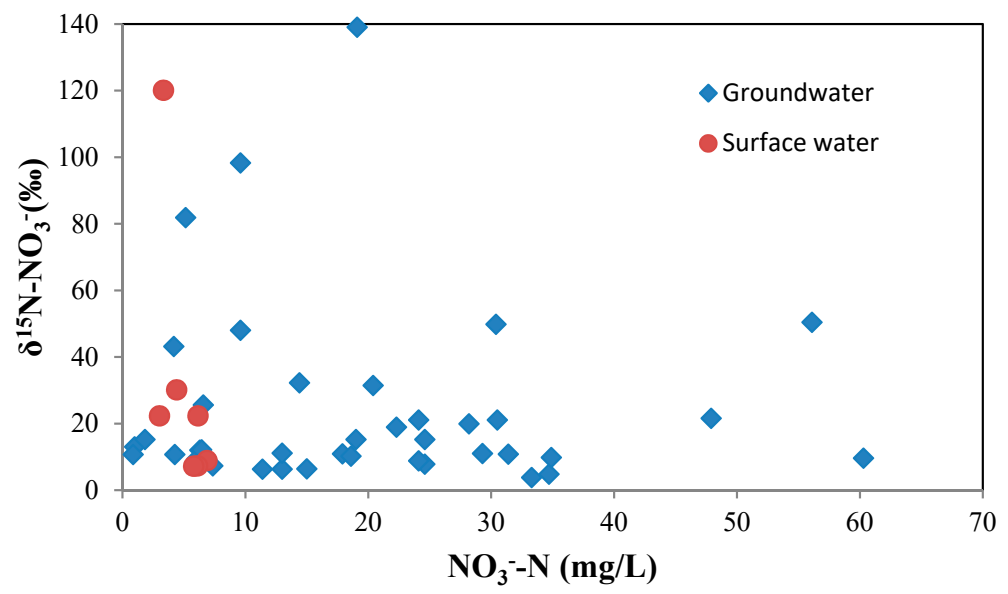

(a)

Figure 7. Cont. 


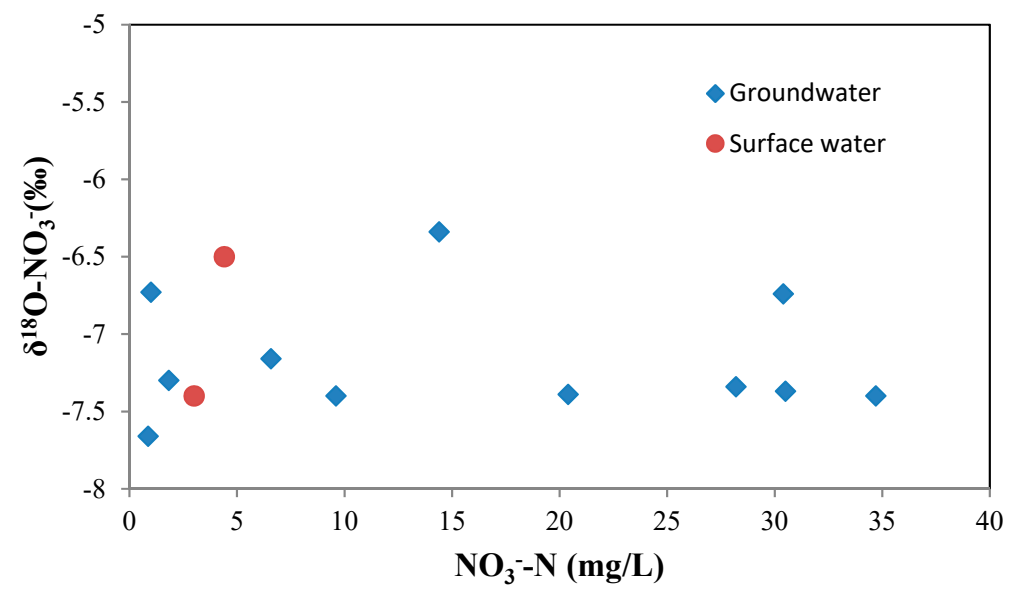

(b)

Figure 7. (a) $\delta^{15} \mathrm{~N}_{-} \mathrm{NO}_{3}$ versus $\mathrm{NO}_{3}{ }^{-}$, and (b) $\delta^{18} \mathrm{O}-\mathrm{NO}_{3}$ versus $\mathrm{NO}_{3}{ }^{-}$for groundwater and surface water.

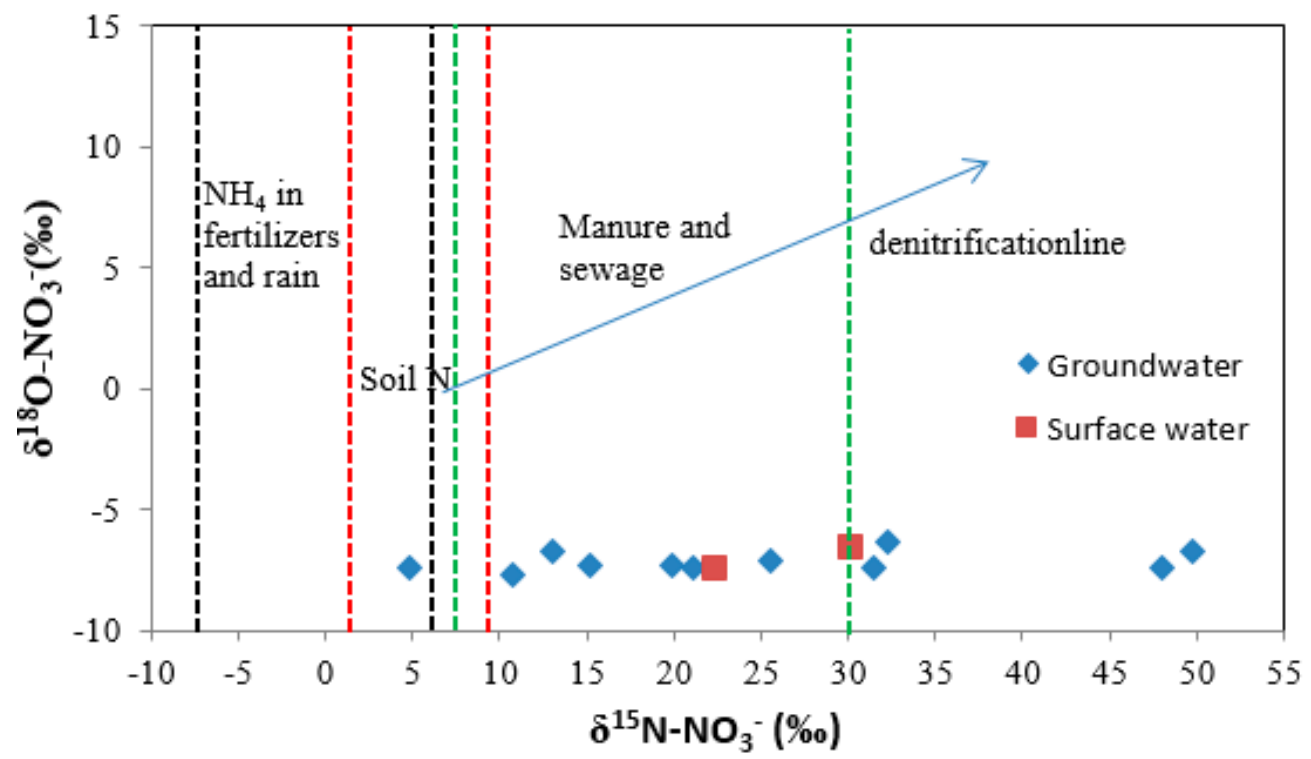

Figure 8. Values of $\delta^{15} \mathrm{~N}-\mathrm{NO}_{3}$ versus $\delta^{18} \mathrm{O}-\mathrm{NO}_{3}$ derived from natural and anthropogenic nitrate sources.

\subsection{The Time of Nitrate Transport from River Water to Groundwater}

Recently, an increasing number of studies on solute transport have been published, including the field observations, data analysis and numerical modelling [16-18,48,49]. However, data are still scarce with respect to the nitrate concentration affected by the over exploitation. Generally, some time is needed for nitrate transport from the river to groundwater. The migration time of groundwater flow near the bank is affected by the hydraulic conductivities of the riverbed sediments and adjacent aquifers, the distance between river and inland wells, and the thickness of riverbed sediments. The nitrate in river water movement into the adjacent aquifers should be considered in zone with groundwater level depression cones. The pollution of river water has little influence on the zone in the west of the groundwater level depression cone. According to the hydraulic conductivity of the river bed and the aquifer, the distance between the wells and river and the thickness of riverbed, the migration time of groundwater flow in the zone of groundwater level depression cone may be calculated. In order to estimate the time of nitrate transport from the river to groundwater, two cases have been considered to compute the time lag of nitrate, i.e., the cases of considering the silt of the riverbed and ignoring it. 
The average time of river water passing through the riverbed is 45 days, considering the influence of bottom sediments of the A-A' section. However, the average migration time of nitrate from the river to the zone of groundwater level depression cone ranges from 56 to 77 days. This indicates that there is obvious hysteresis in the nitrate transporting from the river water to groundwater. As can be seen from Figure 6a, the peak of nitrate concentration in the river water occurred in January 2011; however, that in the well W1 was in March 2011. The peak nitrate concentration in well W2 was not clear. The nitrate concentration in well W2 can be determined to have peaked in April 2011, according to the estimation of the migration time of nitrate contamination in the river. The peak value of nitrate concentration in the river water in January 2011 corresponds to that in well W1 in March 2011 and that in well W2 in April 2011; therefore, the time lag is between two and three months. The average migration time of nitrate from the river to the zone of groundwater level depression cone is 12 to 23 days when the effect of riverbed sediment is not considered. One can see that the time lag of nitrate migration in the nearest well is less than that in the well far away from the river for the A- $\mathrm{A}^{\prime}$ section under the condition of two cases. Taking the case of ignoring the silt of the riverbed as an example, the time lag of nitrate contamination in well W1 is 12 days, while that in well W2 is 23 days. This indicates that the time of contamination transporting to groundwater increases with the distance.

In the transect $B-B^{\prime}$, the average time of river water passing through the riverbed is 59 days, which is larger than that in the transect $A-A^{\prime}$, because the hydraulic conductivity of riverbed sediment in the transect $B-B^{\prime}$ is lower than that in the transect $A-A^{\prime}$. Similar to the transect $A-A^{\prime}$, there is a time lag in the nitrate transporting from the river water to groundwater in the the transect $B-\mathrm{B}^{\prime}$. The average migration time of nitrate from the river to the zone of groundwater level depression cone ranges from 72 to 85 days. In addition, Figure $6 \mathrm{~b}$ shows that the peak value of nitrate concentration in the river appeared in November 2010. However, the peaks of nitrate concentration in the wells W6 and W7 were in March 2011, which indicates that the time lag is four months. The migration time of nitrate from the river to the zone of groundwater level depression cone is ranges from 14 to 27 days when the effect of riverbed sediment is ignored.

Similar to the transects $A-A^{\prime}$ and B-B', the average time of river water passing through the riverbed is 53 days in the transect $C-C^{\prime}$. The average migration time of nitrate from the river to the zone of groundwater level depression cone ranges from 65 to 82 days when the effect of bottom sediments of the river is considered. Additionally, it can be seen from Figure $6 \mathrm{c}$ that there is obvious hysteresis in the nitrate transporting from the river to groundwater. The peak value of nitrate concentration in the river water in November 2010 corresponds to that of well W11 in January 2011 and that of well W12 in May 2011, respectively. Thus, the time lag for the migration of nitrate from the river to groundwater is two to six months, which is longer than that obtained by the analytical method. This is because the migration of nitrate is considered in the analytical method without considering the dispersion effect. However, without consideration of the effect of riverbed sediment, the migration time of nitrate from the river to the zone of groundwater level depression cone ranges from 13 to 20 days.

\section{Conclusions}

In the present study, the variation of groundwater level and nitrate distribution in the alluvial fan area of Luanhe river, North China Plain, was investigated. Based on the field observations, a three-layered structure was identified which is characterized by a high permeable sand layer, a sand gravel layer and a clay aquitard between them. The measured results showed that the groundwater level varied with seasons. During the dry season from November 2010 to April 2011, the observed groundwater level decreased slightly and the groundwater discharged to the river. Then, the groundwater level increased gradually from May to September 2011 during the period of river stage rise. Typically, the river water recharged groundwater from November 2010 to September 2011. The amount of groundwater supplied by the river is $346.3 \times 10^{4} \mathrm{~m}^{3} / \mathrm{a}$, and the discharge of groundwater to the river is about $14.08 \times 10^{4} \mathrm{~m}^{3} /$ a during this period. 
The nitrate concentration of groundwater and river water varied with seasons. The nitrate of groundwater in wells near the river is affected by the river water, and the nitrate concentration variation is basically the same as that of the river. The nitrate concentration decreases as the groundwater level increased from November 2010 to July 2011. The nitrate concentrations in the zone of groundwater level depression cone were lower than those in the wells near the river, due to the long-term pumping of groundwater. However, the nitrate concentration of river water has little influence on that of groundwater in wells far from the river.

The values of $\delta^{15} \mathrm{~N}_{-} \mathrm{NO}_{3}$ and the relationship between the two isotopes $\left(\delta^{15} \mathrm{~N}-\mathrm{NO}_{3}\right.$ and $\left.\delta^{18} \mathrm{O}-\mathrm{NO}_{3}\right)$ were used to judge the nitrate source of groundwater and river water. The results showed that the main sources of nitrate in groundwater are sewage, livestock manure and natural soil organic matter. Due to the existence of a groundwater depression cone near the wells W2, W7 and W12, the nitrate contamination can be transport into the aquifer near the river with the river flow. There is obvious hysteresis in the nitrate transporting from the river water to groundwater. The average time lag of nitrate migration from the river to the zone of groundwater level depression cone is different in different sections, which shows an increasing trend from the upstream to downstream along the river, with an average of two to six months. This is mainly related to the stratigraphic structure, the migration distance, the hydraulic conductivities of the aquifer and the riverbed sediment. Compared with the case of considering the silt layer, the time lag of nitrate migration is greater than that of the case in which the silt layer was ignored. The results will provide useful information for detecting nitrate concentrations in the alluvial fan area of the Luanhe river, northeast of the NCP.

Author Contributions: Q.G. and Z.Z. conceived and designed the study; Q.G. and Z.D. collected and analyzed field data; G.H. and Z.D. analyzed laboratory data; Q.G. wrote the paper with the assistance of Z.Z.

Funding: This research was supported by the National Key R\&D Program of China (No.2016YFC0402803), the National Natural Science Foundation of China (No. 41772235), and the Fundamental Research Funds for the Central Universities (No. 2019B16814). It was also supported by the the Natural Science Foundation of Jiangsu Province of China (No.BK20150799).

Acknowledgments: We gratefully thank the anonymous reviewers for their comments and suggestions on the manuscript.

Conflicts of Interest: The authors declare that there are no conflicts of interest regarding the publication of this paper.

\section{References}

1. Veizaga, E.A.; Ocampo, C.J.; Rodriguez, L. Hydrological and hydrochemical behavior of a riparian zone in a high-order flatland stream. Environ. Monit. Assess. 2019, 191, 10. [CrossRef] [PubMed]

2. Bentivoglio, F.; Calizza, E.; Rossi, D.; Carlino, P.; Careddu, G.; Rossi, L.; Costantini, M.L. Site-scale isotopic variations along a river course help localiza drainage basin influence on river food webs. Hydrobiologia 2016, 770, 257-272. [CrossRef]

3. Peterson, D.; Wilson, J. Variably Saturated Flow between Streams and Aquifers; Available from Tech. Completion Rep. 233; New Mexico Water Resources Research Institute: Socorro, NM, USA, 1988.

4. Sophocleous, M. Interactions between groundwater and surface water: The state of the science. Hydrogeol. J. 2002, 10, 52-67. [CrossRef]

5. Brunner, P.; Cook, P.G.; Simmons, C.T. Hydrogeologic controls on disconnection between surface water and groundwater. Water Resour. Res. 2009, 45, W01422. [CrossRef]

6. Doble, R.; Brunner, P.; McCallum, J.; Cook, P.G. An analysis of river bank slope and unsaturated flow effects on bank storage. Ground Water. 2012, 50, 77-86. [CrossRef] [PubMed]

7. Biddau, R.; Cidu, R.; Da Pelo, S.; Carletti, A.; Ghiglieri, G.; Pittalis, D. Source and fate of nitrate in contaminated groundwater systems: Assessing spatial and temporal variations by hydrogeochemistry and multiple stable isotope tools. Sci. Total Environ. 2019, 647, 1121-1136. [CrossRef] [PubMed]

8. Gibert, O.; Assal, A.; Devlin, H.; Elliot, T.; Kalin, R.M. Performance of a field-scale biological permeable reactive barrier for in-situ remediation of nitrate-contaminated groundwater. Sci. Total Environ. 2019, 659, 211-220. [CrossRef] 
9. Spalding, R.F.; Hirsh, A.J.; Exner, M.E.; Little, N.A.; Kloppenborg, K.L. Applicability of the dual isotopes delta $15 \mathrm{~N}$ and delta $18 \mathrm{O}$ to identify nitrate in groundwater beneath irrigated cropland. J. Contam. Hydrol. 2019, 220, 128-135. [CrossRef]

10. Ascott, M.J.; Gooddy, D.C.; Wang, L.; Stuart, M.E.; Lewis, M.A.; Ward, R.S.; Binley, A.M. Global patterns of nitrate storage in the vadose zone. Nat. Commun. 2017, 8, 1416. [CrossRef]

11. Goss, M.J.; Barry, D.A.J.; Rudolph, D.L. Contamination in Ontario farmstead domestic wells and its association with agriculture:1. results from drinking water wells. J. Contam. Hydrol. 1998, 32, 267-293. [CrossRef]

12. Thorburn, P.J.; Biggs, J.S.; Weier, K.L.; Keating, B.A. Nitrate in groundwaters of intensive agricultural areas in coastal Northeastern Australia. Agric. Ecosyst. Environ. 2003, 94, 49-58. [CrossRef]

13. Wu, M.; Wu, J.F.; Liu, J.; Wu, J.C.; Zheng, C.M. Effect of groundwater quality on sustainability of groundwater resource: A case study in the North China Plain. J. Contam. Hydrol. 2015, 179, 132-147. [CrossRef] [PubMed]

14. Chen, J.; Tang, C.; Sakura, Y.; Yu, J.; Fukushima, Y. Nitrate pollution from agriculture in different hydrogeologicalzones of the regional groundwater flow system in the North China Plain. Hydrogeol. J. 2005, 13, 481-492. [CrossRef]

15. Oenema, O.; van Liere, L.; Schoumans, O. Effects of lowering nitrogen and phosphorus surpluses in agriculture on the quality of groundwater and surface water in the Netherlands. J. Hydrol. 2005, 304, 289-301. [CrossRef]

16. Chen, J.Y.; Taniguchi, M.; Liu, G.Q.; Miyaoka, K.; Onodera, S.I.; Tokunaga, T.; Fukushima, Y. Nitrate pollution of groundwater in the Yellow River delta, China. Hydrogeol. J. 2007, 15, 1605-1614. [CrossRef]

17. Pang, Z.H.; Yuan, L.J.; Huang, T.M.; Kong, Y.L.; Liu, J.L.; Li, Y.M. Impacts of human activities on the occurrence of groundwater nitrate in an alluvial plain: A multiple isotopic tracers approach. J. Earth Sci. 2013, 24, 111-124. [CrossRef]

18. Cao, G.L.; Scanlon, B.R.; Han, D.M.; Zheng, C.M. Impacts of thickening unsaturated zone on groundwater recharge in the North China Plain. J. Hydrol. 2016, 537, 260-270. [CrossRef]

19. Johannsen, A.; Dähnke, K.; Emeis, K. Isotopic composition of nitrate in five German rivers discharging into the North Sea. Org. Geochem. 2008, 39, 1678-1689. [CrossRef]

20. Xue, D.; Botte, J.; De Baets, B.; Accoe, F.; Nestler, A.; Taylor, P.; Van Cleemput, O.; Berglund, M.; Boeckx, P. Present limitations and future prospects of stable isotope methods for nitrate source identification in surfaceandgroundwater. Water Res. 2009, 43, 1159-1170. [CrossRef]

21. Voss, M.; Deutsch, B.; Elmgren, R.; Humborg, C.; Kuuppo, P.; Pastuszak, M.; Rolff, C.; Schulte, U. Sources identification of nitrate by means of isotopic tracers in the Baltic Sea catchments. Biogeosciences 2006, 3, 663-676. [CrossRef]

22. Lee, K.S.; Bong, Y.S.; Lee, D.; Kim, Y.; Kim, K. Tracing the sources of nitrate in the Han River watershed in Korea, using $\delta^{15} \mathrm{~N}^{-\mathrm{NO}_{3}}$ and $\delta^{18} \mathrm{O}-\mathrm{NO}_{3}$ values. Sci. Total Environ. 2008, 395, 117-124. [CrossRef] [PubMed]

23. Gutierrez, M.; Biagioni, R.N.; Alarcon-Herrera, M.T.; Rivas-Lucero, B.A. An overview of nitrate sources and operating processes in arid and semiarid aquifer systems. Sci. Total Environ. 2018, 624, 1513-1522. [CrossRef] [PubMed]

24. Phillips, D.L.; Koch, P.L. Incorporating concentration dependence in stable isotope mixing models. Oecologia 2002, 130, 114-125. [CrossRef] [PubMed]

25. Deutsch, B.; Mewes, M.; Liskow, I.; Voss, M. Quantification of diffuse nitrate inputs into a small river system using stable isotopes of oxygen and nitrogen in nitrate. Org. Geochem. 2006, 37, 1333-1342. [CrossRef]

26. Matiatos, I. Nitrate source identification in groundwater of multiple land-use areas by combining isotopes and multivariate statistical analysis: A case study of Asopos basin (Central Greece). Sci. Total Environ. 2016, 541, 802-814. [CrossRef] [PubMed]

27. Kendall, C. Tracing sources and cycling of nitrate in catchments. In Isotope Tracers in Catchment Hydrology; Kendall, C., McDonnell, J.J., Eds.; Elsevier: Amsterdam, The Netherlands, 1998; pp. 519-576.

28. Durka, W.; Schulze, E.D.; Gebauer, G.; Voerkelius, S. Effects of forest decline on uptake and leaching of deposited nitrate determined from ${ }^{15} \mathrm{~N}$ and ${ }^{18}$ Omeasurements. Nature 1994, 372, 765-767. [CrossRef]

29. Mayer, B.; Boyer, E.W.; Goodale, C.; Jaworski, N.A.; Breemen, N.V.; Howarth, R.W. Sources of nitrate in rivers draining sixteen watersheds in the northeastern U.S.: Isotopic constraints. Biogeochemistry 2002, 57-58, 171-197. [CrossRef] 
30. Findlay, S. Importance of surface-subsurface the hyporheic zone exchange in stream ecosystems. Limnol. Oceanogr. 1995, 40, 159-164. [CrossRef]

31. Cirpka, O.A.; Fienen, M.N.; Hofer, M.; Hoehn, E.; Tessarini, A.; Kipfer, R.; Kitanidis, P.K. Analyzing bank filtration by deconvoluting time series of electric conductivity. Ground Water 2007, 45, 318-328. [CrossRef] [PubMed]

32. Hunt, R.J.; Coplen, T.B.; Haas, N.L.; Saad, D.A.; Borchardt, M.A. Investigating surface water-well interaction using stable isotope ratios of water. J. Hydrol. 2005, 302, 154-172. [CrossRef]

33. Vogt, T.; Hoehn, E.; Schneider, P.; Freund, A.; Schirmer, M.; Cirpka, O.A. Fluctuations of electrical conductivity as a natural tracer for bank filtration in a losing stream. Adv. Water Resour. 2010, 33, 1296-1308. [CrossRef]

34. Vero, S.E.; Basu, N.B.; Van Meter, K.; Richards, K.G.; Mellander, P.E.; Healy, M.G.; Fenton, O. Review: The environmental status and implications of the nitrate time lag in Europe and North America. Hydrogeol. J. 2018, 26, 7-22. [CrossRef]

35. Song, F.; She, S.Q.; Liu, X.S. Groundwater vulnerability assessment system in alluvial fan of Luanhe river. Environ. Sci. Technol. 2005, 28, 116-118.

36. Huang, Y.; Zhou, Z.F.; Wang, J.G.; Dou, Z.; Guo, Q.N. Spatial and temporal variability of the chemistry of the shallow groundwater in the alluvial fan area of the Luanhe river, North China. Environ. Earth Sci. 2014, 72, 5123-5137. [CrossRef]

37. Epstein, S.; Mayeda, T. Variation of ${ }^{18} \mathrm{O}$ content of waters from natural sources. Geochim. Cosmochim. Acta 1953, 4, 213-224. [CrossRef]

38. Vaux, W.G. Intragravel flow in interchange of water in a streambed US Fish Wildlife. Serv. Fish. Bull. 1968, $66,479-489$.

39. Woessener, W.W. Stream and fluvial plain ground water interactions: Rescalinghydrogeologic thought. Ground Water 2000, 38, 423-429. [CrossRef]

40. Brodie, R.; Sundaram, B.; Tottenham, R.; Hostetler, S.; Ransley, T. An Overview of Tools for Assessing Groundwater-Surface Water Connectivity; Bureau of Rural Sciences: Canberra, Australia, 2007.

41. Mencio, A.; Galan, M.; Boix, D.; Mas-Pla, J. Analysis of stream-aquifer relationships: A comparison between mass balance and Darcy's law approaches. J. Hydrol. 2014, 517, 157-172. [CrossRef]

42. Heaton, T.H.E. Isotopic studies of nitrogen pollution in the hydrosphere and atmosphere: A review. Chem. Geol. 1986, 59, 87-102. [CrossRef]

43. Fogg, G.E.; Rolston, D.E.; Decker, D.L.; Louie, D.T.; Grismer, M.E. Spatial variation in nitrogen isotope values beneath nitrate contamination sources. Ground Water 1998, 36, 418-426. [CrossRef]

44. Kent, R.; Landon, M.K. Trends in concentrations of nitrate and total dissolved solids in public supply wells of the Bunker Hill, Lytle, Rialto, and Colton groundwater sub basins, San Bernardino County, California: Influence of legacy land use. Sci. Total Environ. 2013, 452-453, 125-136. [CrossRef] [PubMed]

45. Fukada, T.; Hiscock, K.M.; Dennis, P.F. A dual-isotope approach to the nitrogenhydrochemistry of an urban aquifer. Appl. Geochem. 2004, 19, 709-719. [CrossRef]

46. Jin, Z.F.; Pan, Z.Y.; Jin, M.T.; Li, F.L.; Wan, Y.; Gu, B. Determination of nitrate contamination sources using isotopic and chemical indicators in an agricultural region in China. Agric. Ecosyst. Environ. 2012, 155, 78-86. [CrossRef]

47. Bu, H.M.; Song, X.F.; Zhang, Y.; Meng, W. Sources and fate of nitrate in the Haicheng River basin in Northeast China using stable isotopes of nitrate. Ecol. Eng. 2017, 98, 105-113. [CrossRef]

48. Dou, Z.; Chen, Z.; Zhou, Z.; Wang, J.; Huang, Y. Influence of eddies on conservative solute transport through a 2D single self-affine fracture. Int. J. Heat Mass Transf. 2018, 121, 597-606. [CrossRef]

49. Dou, Z.; Zhou, Z.; Wang, J.; Huang, Y. Roughness scale dependence of the relationship between tracer longitudinal dispersion and Peclet number in variable-aperture fractures. Hydrol. Process. 2018, 32, 1461-1475. [CrossRef]

(C) 2019 by the authors. Licensee MDPI, Basel, Switzerland. This article is an open access article distributed under the terms and conditions of the Creative Commons Attribution (CC BY) license (http:/ / creativecommons.org/licenses/by/4.0/). 